\title{
Tracheobronchitis Caused by Methicillin-Resistant Staphylococcus aureus as a Cause of Chronic Wheezing in a Non-Ventilated Adult Patient with Tracheobronchomalacia
}

\author{
Theodoros Kelesidis $^{\mathrm{a}} \quad$ Sara Osman $^{\mathrm{a}} \quad$ Edward Trayner ${ }^{\mathrm{b}} \quad$ Michael Worthington ${ }^{\mathrm{c}}$ \\ Bartolome Cellib \\ a Department of Medicine, and Divisions of b Pulmonary Medicine and Critical Care, and ${ }^{\mathrm{C}}$ Infectious Diseases, \\ Caritas St. Elizabeth's Medical Center, Tufts University School of Medicine, Boston, Mass., USA
}

\section{Established Facts}

- Although bacterial tracheobronchitis is a rare entity (long considered to be a pediatric disease), a different form of tracheobronchitis, called exudative tracheitis (ET), has recently been described in patients without any signs of systemic infection.

- The diagnosis of tracheomalacia in adults can masquerade as persistent asthma.

\section{Novel Insights}

- The first case of methicillin-resistant Staphylococcus aureus (MRSA) exudative tracheobronchitis and tracheomalacia in a non-ventilated adult.

- We also suggest, based on published scientific evidence, that colonization of sputum with MRSA and development of tracheobronchitis can potentially contribute to the development of tracheobronchomalacia and lead to multiple exacerbations of COPD, as was noticed in our patient.

\section{Key Words}

MRSA · Staphylococcus aureus • Tracheobronchitis •

Tracheobronchomalacia

\section{Abstract}

Bacterial tracheobronchitis is an extremely rare entity, which was long considered to be a pediatric disease. We report the case of a 65-year-old woman who presented with persistent wheezing, worsening productive cough and sore throat. Computed tomography of the chest revealed the presence of tracheomalacia, confirmed at bronchoscopy. The presence of purulent exudate, coating the trachea and main bronchi, was consistent with bacterial tracheobronchitis. Culture of the tracheal aspirates grew methicillin-resistant Staphylococcus aureus (MRSA). As the patient was afebrile

\section{KARGER}

Fax +41613061234 E-Mail karger@karger.ch www.karger.com
(C) 2009 S. Karger AG, Basel

0025-7931/10/0802-0148\$26.00/0

Accessible online at:

www.karger.com/res
Theodoros Kelesidis, MD

Department of Medicine, Caritas St. Elizabeth's Medical Center

Tufts University School of Medicine, 736 Cambridge Street

Boston, MA 02135 (USA)

Tel. +1 617789 3000, Fax +1 617787 0452, E-Mail tkelesid@ gmail.com 
and not systemically ill, the clinical picture was consistent with exudative tracheobronchitis. To our knowledge, this is the first case of MRSA exudative tracheobronchitis and tracheomalacia in a non-ventilated adult. Other adult cases of bacterial tracheobronchitis and MRSA tracheobronchitis in mechanically ventilated patients reported in the literature are also reviewed. Physicians should be aware of the diagnosis of tracheomalacia in adults, which can masquerade as persistent asthma and may be associated with the development of serious infections including MRSA tracheobronchitis.

Copyright @ 2009 S. Karger AG, Basel

\section{Introduction}

Bacterial tracheobronchitis is a clinical entity that has mainly been described in the pediatric population. It rarely occurs in adults, except in patients who are intubated and mechanically ventilated $[1,2]$. A different form of tracheobronchitis called exudative tracheitis (ET) has recently been described [3] in patients without any signs of systemic infection.

Methicillin-resistant Staphylococcus aureus (MRSA) is a major nosocomial pathogen and its incidence has been increasing during the last decades in the community, in hospitals and in long-term care facilities. MRSA tracheitis is very rare in the adult population, with only 2 cases being described in non-ventilated patients $[4,5]$.

Tracheobronchomalacia in adults is an underdiagnosed clinical entity characterized by excessive collapsibility of trachea or bronchi. Its acquired form is associated with many clinical conditions, including chronic obstructive pulmonary disease (COPD), chronic infection and chronic use of corticosteroids.

We describe a case of tracheomalacia in a woman who presented with chronic refractory COPD, characterized by 17 admissions for recurrent wheezing and shortness of breath during the last 2 years. Once tracheomalacia was identified on CT scan of the chest, bronchoscopy confirmed tracheomalacia and ET caused by MRSA. In this report, we summarize the available literature regarding cases of tracheobronchitis in adults caused by MRSA.

\section{Case Report}

A 65-year-old Hispanic female with a history of tobacco use (25 pack years) and a diagnosis of COPD presented with worsening productive cough and dyspnea. In the last 2 years, she had multiple admissions to the hospital for persistent wheezing and

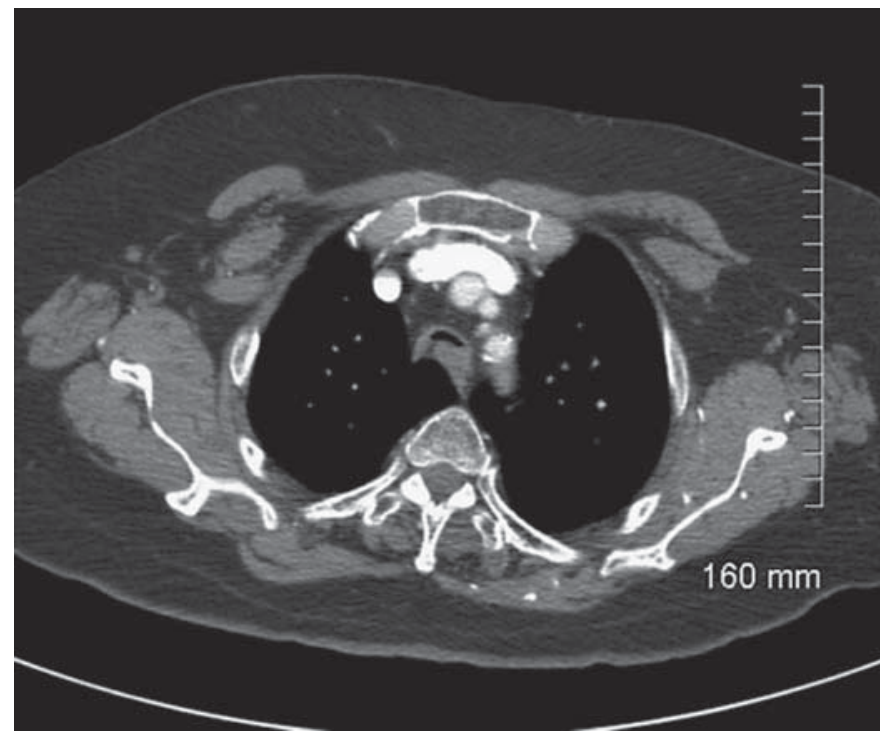

Fig. 1. Axial CT scan shows excessive reduction in tracheal lumen, consistent with tracheomalacia.

COPD exacerbations. Her last pulmonary function tests 2 years prior to this admission had revealed a mild-moderate obstructive pattern which was minimally reversible. Due to her persistent wheezing, the patient had also been diagnosed as asthmatic in the past. Her most recent hospitalization occurred 1 week prior to this admission and for that she was being treated with corticosteroids. She also complained of chronic hoarseness which was attributed to a previous stroke. On physical examination, she was afebrile, hemodynamically stable and her oxygen saturation was $97 \%$ on room air. She had diffuse expiratory wheezing but no stridor. Her white blood cell count at the time of admission was $8,100 / \mathrm{ml}$ with $79 \%$ polymorphonuclear cells. A Gram stain from the sputum and tracheal aspirate revealed Gram-positive cocci in clusters, 25 polymorphonuclear cells per low power field, and 0-5 squamous epithelial cells, whereas the culture showed moderate growth of MRSA, which was sensitive to vancomycin, trimethoprim-sulfamethoxazole, tetracycline and rifampin. A chest roentgenogram revealed cardiomegaly but no infiltrate. A computed tomography scan of the chest revealed marked narrowing of the trachea consistent with tracheomalacia and absence of lung infiltrates (fig. 1). Spirometry showed $\mathrm{FEV}_{1}$ of 2.34 liters (86\%) and FVC of 3.48 liters (107\% of reference value). Although the volume-time curve did not have morphologic alterations, visual inspection of the flow-volume loop revealed reproducible flow oscillations on the expiratory curve consistent with tracheobronchomalacia. A bronchoscopy confirmed the diagnosis of tracheobronchomalacia (fig. 2) and revealed the presence of purulent thick secretions coating the trachea. The patient was treated with nebulizers (ipratropium bromide and albuterol sulfate), corticosteroids, vancomycin and levofloxacin for a total of 8 days and was referred for placement of an endotracheal stent as treatment of her tracheomalacia. 


\section{Discussion}

Bacterial tracheitis has been described almost exclusively in the pediatric population, and its clinical manifestations, microbiology, radiographic findings and treatment in that population have been reviewed elsewhere [6-8]. In adults, bacterial tracheobronchitis is occasionally seen in patients who are intubated and mechanically ventilated $[1,2]$. Ventilation-associated tracheobronchitis (VAT) is probably an intermediate process between lower respiratory tract colonization and ventilation-associated pneumonia $[9,10]$. VAT should be suspected in intubated patients with clinical signs of lower respiratory tract infection (such as fever, leukocytosis and purulent sputum) with a Gram stain demonstrating microorganisms and polymorphonuclear leukocytes, with either semi-quantitative or quantitative cultures in the absence of new or progressive infiltrates on chest roentgenograms $[10,11]$. VAT is difficult to differentiate from colonization. Quantitative criteria may help discriminate between lower airway colonization and infection [12]. Moderate-heavy growth of a pathogen(s) is usually considered significant in semi-quantitative cultures of the endotracheal aspirate. The complex interactions between the quantity and virulence of the bacterial pathogen(s) entering the lower respiratory tract and the patient's host defenses determine if colonization will progress to VAT, and in some cases to ventilation-associated pneumonia $[13,14]$. Bacterial virulence is also very important and clearly varies between and within species including Gram-positive species of MRSA [15].

The crude incidence of VAT varies from 2.7 to $10 \%$ [11, 16, 17]. Common pathogens for VAT include Pseudomonas aeruginosa, Acinetobacter spp. and MRSA [11, 17]. Nosocomial tracheobronchitis is associated with an increased length of stay and duration of mechanical ventilation in both surgical and medical patients [11] and in patients without chronic respiratory failure [18].

Some physicians consider VAT to be simple colonization whereas others routinely treat patients with VAT [19, 20]. Data from two recent randomized clinical trials [9] support the latter approach with targeted antibiotic therapy resulting in shorter duration of mechanical ventilation and intensive care unit stay [21]. However, since extensive use of antimicrobial agents is associated with selection of multidrug-resistant pathogens and complications such as Clostridium difficile colitis [10], the riskbenefit ratio for using antibiotic therapy for VAT needs further evaluation in clinical trials.

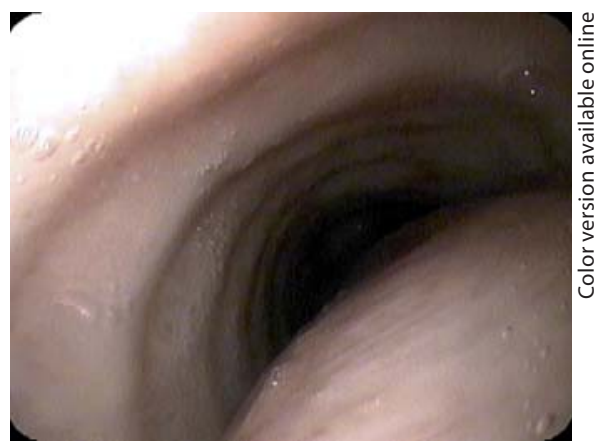

Fig. 2. Bronchoscopy revealed bowing of the posterior wall and excessive reduction in the tracheal lumen during expiration consistent with tracheomalacia.

Risk factors that are associated with the development of tracheobronchitis include virus-induced impairment in mucocilliary clearance of organisms [6, 22], immune deficiency [23] and mechanical ventilation [24]. In one study of patients $>60$ years, COPD and antimicrobial therapy during the 2 weeks preceding intensive care unit admission was significantly associated with nosocomial tracheobronchitis [11]. COPD is associated with impaired mucosal clearance which predisposes to colonization by bacteria $[25,26]$ and can cause further bacterial adherence, growth and dysfunction of host defenses [27]. Presence of preexisting anatomic pathology in the airways such as repaired tracheoesophageal fistula [28] or following tracheal mucosal injury [29] may facilitate the development of bacterial tracheitis in children. In only 1 case in the literature has tracheobronchomalacia been described as a probable risk factor for the development of bacterial tracheitis in a 3-year-old male [30]. However, to our knowledge, tracheobronchitis in adults has not been associated with tracheomalacia previously, and this clinical entity in non-ventilated adults has not been reviewed in the literature to date.

According to the Centers for Disease Control (CDC) criteria [31], tracheobronchial infections were defined as follows: fever $\left(>38^{\circ} \mathrm{C}\right)$ with no other recognizable cause, new or increased sputum production and a positive tracheal aspirate culture without radiographic evidence of pneumonia. We completed our PubMed search (from 1980 to November 2008) of the English literature applying the term 'tracheobronchitis, tracheitis.' Using the CDC definition, and to avoid potential ambiguity of the clinical diagnosis of bacterial tracheitis, only patients with endoscopic confirmation were included. The references cited in these articles were examined to identify 
additional reports. We found 35 cases of tracheobronchitis in non-ventilated adults [4, 5, 32-45]. We excluded 19 of them since the diagnosis was not based on endoscopic findings [34, 35, 43-45]. Five cases were not from the English literature and were also excluded [5, 39]. Thus 11 cases were included in our analysis (table 1$)[4,32,33$, 36-38, 40-42]. Females seem to have a higher incidence of tracheobronchitis than males $(8 / 11,72.7 \%)$. Some authors postulate that the smaller size of the trachea in females renders them more susceptible to tracheitis [42]. All 3 males were immunocompromised either from HIV infection [37], from chronic steroid use [38] or from recent systemic viral illness [4]. On the other hand, only $25 \%(2 / 8)$ of female patients were immunocompromised (underlying malignancy) [36, 42]. However, the rarity of the condition prohibits definite characterization of its epidemiology. Bronchoscopy was used for diagnosis of tracheobronchitis in 5/10 (50\%) cases [4, 36-38, 42], laryngoscopy in $6 / 10(60 \%)$ cases $[33,37,40-42]$ and both methods were used in 1 case [37]. The diagnosis was based on autopsy in 1 case [32]. S. aureus was isolated in 7/9 $(77.8 \%)$ cases, and only in 1 case was the agent identified as MRSA [4]. No cultures were sent in 2 cases [33, 42]. Mortality was noticed to be $18.2 \%$ in the cases reviewed $(2 / 11)$

\section{Exudative Tracheitis}

Salamone et al. [3] have suggested that the term ET is a more accurate descriptive term than bacterial tracheitis for the patients who did not have the classic description of the toxic, febrile patient with stridor [3]. This implies that bacterial tracheitis may be more of a local process caused by bacteria or virus which leads to the formation of tracheobronchial exudates [3]. The results of another study also suggest that bacterial tracheitis may be a less morbid condition [46]. ET may represent a point on a continuum of disease from mild upper-respiratory infection to severe bacterial tracheitis. Although less severe than classic bacterial tracheitis, patients with ET require aggressive local and systemic management as obstruction and respiratory collapse can occur. Treatment includes bronchoscopy with removal of the characteristic thick tracheal membranes associated with intravenous antibiotics. Patients with ET recover rapidly with appropriate management. Intubation is not always necessary, and multiple debridement procedures are typically not needed.

\section{MRSA Tracheitis}

MRSA is now endemic in hospitals and long-term care facilities [47]. In adults, MRSA is frequently seen in the elderly, and most of the patients have a history of hospitalization. MRSA tracheitis is almost exclusively diagnosed in ventilated patients diagnosed with VAT. Underlying risk factors for MRSA respiratory infection include underlying COPD, prior use of antibiotics and multiple hospitalizations [20]. In table 2, we summarize all the studies that have described MRSA isolates from VAT patients [9-11, 18, 21]. However, tracheitis that develops in a previously healthy patient is a distinctly different process from tracheitis that occurs in a patient with an artificial airway. Only 2 cases of MRSA tracheitis have been described in non-ventilated patients $[4,5]$. The incidence of MRSA as cause of VAT ranged between 11 and 15.9\% $[9-11,18,21]$. In the largest of these studies, in 201 cases of nosocomial tracheobronchitis in mechanically ventilated patients, 31 cases (15.4\%) were secondary to MRSA and 6 cases (3\%) were secondary to methicillin-sensitive S. aureus (MSSA) [11]. Antimicrobial agents that have been reported as efficacious in the treatment of MRSArelated infections include vancomycin, linezolid, clindamycin, trimethoprim-sulfamethoxazole and rifampin (table 2). One study suggests that oral linezolid offers an effective alternative to intravenous vancomycin for the treatment of MRSA tracheitis [48]. Two cases of MRSA tracheitis were treated for 2 and 3 days with intravenous vancomycin, and therapy was changed to enteral linezolid (10 mg/kg every $12 \mathrm{~h}$ ) to finish a 10-day course [48]. Both patients completed the therapy without the need for rehospitalization. Saralaya et al. [49] demonstrated the efficacy of a dosing regimen of linezolid of $600 \mathrm{mg}$ by mouth every $12 \mathrm{~h}$ in adults with cystic fibrosis. However, there is no experience regarding the use of other agents such as trimethoprim-sulfamethoxazole, clindamycin or rifampin in the treatment of tracheitis caused by MRSA.

\section{Tracheobronchomalacia}

Tracheobronchomalacia, characterized by excessive collapsibility of trachea or bronchi, is an important cause of nonspecific pulmonary symptoms [50] that is frequently underrecognized. Previous studies reported an incidence of tracheobronchomalacia of 1-23\%, depending on the populations studied [51, 52]. It is rare in individuals without some evidence of obstructive lung disease [50]. Tracheobronchomalacia may be congenital or acquired [50]. Acquired tracheomalacia is caused by the degeneration of normal cartilaginous support from a variety of causes and may result from endotracheal tubes and tracheostomy, COPD, external trauma and lung surgery, chronic compression of the trachea, radiation therapy, relapsing polychondritis, and chronic or recurrent 
Table 1. Cases of bacterial tracheobronchitis in non-ventilated adults diagnosed endoscopically

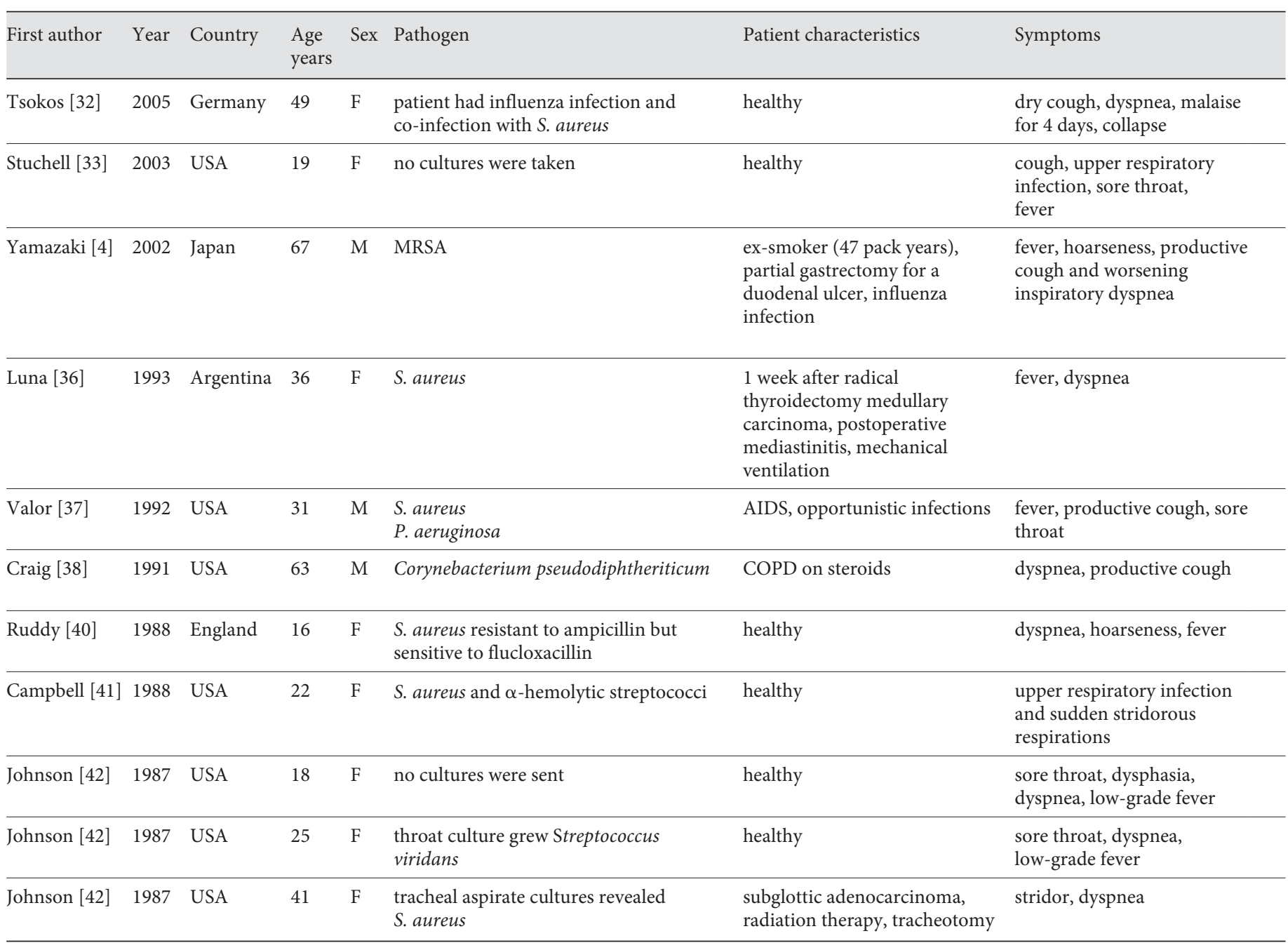

infection [50]. The use of high-dose steroids may also predispose patients to developing progressive tracheobronchomalacia [50]. The diagnosis of tracheobronchomalacia has historically been made with fluoroscopy or bronchoscopy [53], but recent advances in CT technology have made it possible to diagnose this process using this technique $[53,54]$.

\section{Our Case}

The purulent nature of the secretions localized in the trachea and main bronchi, and the isolation and moderate growth of a single predominant bacterial pathogen in semi-quantitative respiratory cultures in a patient without toxic symptoms and without pulmonary infiltrates on CT scan is consistent with tracheitis. The patient had chronic symptoms of hoarseness, throat pain and productive cough and wheezing for the last 2 years prior to this admission. She also had multiple admissions to the hospital for COPD exacerbation. Interestingly, MRSA had been isolated from her sputum on 6 different admissions but the patient had not undergone diagnostic CT imaging or bronchoscopy. In our opinion, chronic wheezing was secondary to tracheomalacia and the constant productive cough to ET secondary to MRSA which did not respond to multiple courses of quinolones. The use of multiple antibiotics and repeated hospitalizations most likely predisposed this patient to colonization of sputum with MRSA, whereas the anatomy of this patient's airway with narrowing and collapse of the lumen of the trachea secondary to tracheomalacia may have predisposed this 


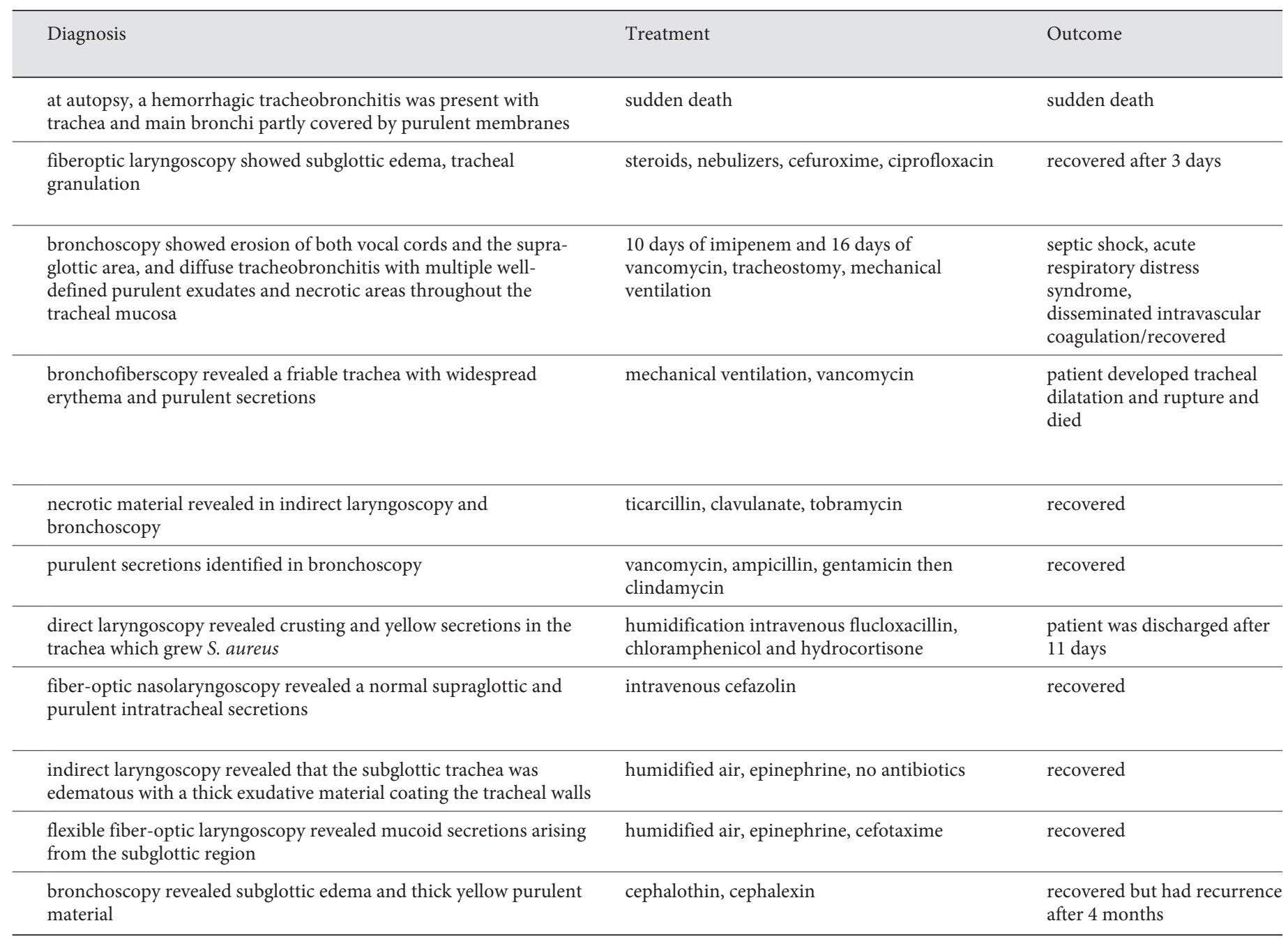

adult to tracheitis. Our case resembles that of an adult with congenital long-segment tracheal stenosis presenting as a difficult-to-treat asthmatic [55]. The authors concluded that her episodes of asthma were in fact dynamic airway narrowing when her tracheobronchial tree was compromised further from infection and inflammation [55]. Risk factors for the development of tracheomalacia in our patient include chronic use of corticosteroids and chronic infection [50]. There is also a possible association between chronic colonization with MRSA and the development of tracheomalacia. Colonization and recurrent infections of the airways with $S$. aureus occur in many patients with cystic fibrosis and lead to increased morbidity and mortality [56]. However, there is limited experience from cases of $S$. aureus tracheitis in non-ventilated adult patients without cystic fibrosis. Multiple episodes of exudative tracheobronchitis might increase the tracheal and bronchial wall compliance and may have predisposed to the development of tracheobronchomalacia [57]. In a recent study, it was shown that $S$. aureus $\alpha$-toxin significantly increases airway epithelial $\mathrm{P}$ and produces epithelial sloughing, which may imply that other $S$. aureussoluble proteins with potent immunomodulatory effects may thereby enter the subepithelial tissue space and play a role in the pathogenesis of $S$. aureus respiratory infections [58]. In only 1 case in the literature, infectious staphylococcal tracheitis was considered a possible cause of tracheal dilatation and rupture in the presence of normal intracuff pressure [36]. 
Table 2. Studies describing MRSA isolates from patients with VAT (diagnosis based on CDC criteria)

\begin{tabular}{|c|c|c|c|c|c|c|c|}
\hline First author & Year & Country & Age, years & Sex & Pathogen & Patient characteristics & Outcome \\
\hline Palmer [10] & 2008 & USA & $62 \pm 20$ & $28 \mathrm{M}, 15 \mathrm{~F}$ & $\begin{array}{l}\text { in a study of } 43 \text { patients with VAT } \\
6(14 \%) \text { had MRSA and } 8(18.6 \%) \\
\text { bacterial isolates were MSSA [10] }\end{array}$ & $\begin{array}{l}\text { all } 43 \text { patients had } \\
\text { mechanical ventilation } \\
3 \text { had COPD }\end{array}$ & $\begin{array}{l}8(18.6 \%) \\
\text { patients } \\
\text { died }\end{array}$ \\
\hline Nseir [18] & 2005 & USA & $59.9 \pm 18.2$ & $\begin{array}{l}31 \mathrm{M}(56 \%) \\
24 \mathrm{~F}\end{array}$ & $\begin{array}{l}55 \text { cases of VAT; the more frequently } \\
\text { isolated bacteria were P. aeruginosa } \\
(34 \%) \text {, Acinetobacter baumannii } \\
(18 \%) \text { and MRSA } 10 / 86(11.6 \%) \\
\text { isolates (11\%), } 30 \text { ( } 54 \% \text { ) VAT } \\
\text { episodes were polymicrobial, and } 31 \\
\text { (56\%) were related to multidrug- } \\
\text { resistant bacteria }\end{array}$ & $\begin{array}{l}12(21 \%) \text { had diabetes } \\
\text { mellitus } \\
14(25 \%) \text { had renal failure } \\
12(21 \%) \text { had } \\
\text { tracheostomy }\end{array}$ & $\begin{array}{l}16(29 \%) \\
\text { patients died }\end{array}$ \\
\hline Nseir [21] & 2004 & USA & $68.8 \pm 7$ & $57 \mathrm{M}(70.3 \%)$ & $\begin{array}{l}19 / 120(15.8 \%) \text { bacterial isolates } \\
\text { from } 81 \text { patients with nosocomial } \\
\text { tracheobronchitis were MRSA and } \\
6 / 120(0.5 \%) \text { were MSSA }\end{array}$ & $\begin{array}{l}\text { all } 81 \text { patients were } \\
\text { ventilated, } 11(13.5 \%) \\
\text { patients had diabetes, } 52 \\
(64.1 \%) \text { had COPD }\end{array}$ & $\begin{array}{l}33(40.7 \%) \\
\text { patients died }\end{array}$ \\
\hline \multirow[t]{3}{*}{ Nseir [11] } & 2002 & USA & $\begin{array}{l}21 / 36 \\
(58.3 \%) \\
>60 \text { years }\end{array}$ & $\begin{array}{l}26 \mathrm{M}(72.2 \%) \\
\text { surgical } \\
\text { patients }\end{array}$ & $\begin{array}{l}7 / 44(15.9 \%) \text { bacterial isolates from } \\
36 \text { surgical patients with nosocomial } \\
\text { tracheobronchitis were MRSA and } \\
2 / 44(4.5 \%) \text { were MSSA }\end{array}$ & $\begin{array}{l}\text { all patients were } \\
\text { ventilated }\end{array}$ & $\begin{array}{l}19(52.7 \%) \\
\text { surgical } \\
\text { patients died }\end{array}$ \\
\hline & & & $\begin{array}{l}131 / 165 \\
(79.4 \%) \\
>60 \text { years }\end{array}$ & $\begin{array}{l}112 \mathrm{M}(67.8 \%) \\
\text { medical patients }\end{array}$ & $\begin{array}{l}31 / 207(14.9 \%) \text { bacterial isolates } \\
\text { from } 165 \text { medical patients with } \\
\text { nosocomial tracheobronchitis were } \\
\text { MRSA and } 6 / 207(2.8 \%) \text { were MSSA }\end{array}$ & $\begin{array}{l}13(36.1 \%) \text { surgical } \\
\text { patients had COPD and } 6 \\
(16.6 \%) \text { had diabetes }\end{array}$ & $\begin{array}{l}69(41.8 \%) \\
\text { medical } \\
\text { patients died }\end{array}$ \\
\hline & & & & & & $\begin{array}{l}118(71.5 \%) \text { medical } \\
\text { patients had COPD and } \\
27(16.4 \%) \text { had diabetes }\end{array}$ & \\
\hline
\end{tabular}

MRSA was isolated from the sputum of our patient over the last 3 years, but it is unclear whether this contributed to her multiple hospitalizations for COPD exacerbation. Several studies showed that the isolation rate of potential bacterial pathogens from sputum samples during stable disease was identical to the rate during acute exacerbations $[59,60]$. This finding led to the conclusion that bacterial pathogens do not cause acute exacerbations and their presence in sputum is due to chronic colonization. However, it has recently been demonstrated that lower airway bacterial colonization in the stable state modulates the character and frequency of COPD exacerbations [27]. In a prospective study using molecular typing of sputum isolates, it was found that the acquisition of a new strain of a bacterial pathogen was significantly associated with acute exacerbations of COPD, leading to the conclusion that this finding supports the causative role of bacteria in COPD exacerbation [61]. A recent prospective study demonstrated that rising airway bacterial load and species changes were associated with greater airway inflammation and accelerated decline in $\mathrm{FEV}_{1}$, suggesting that bacterial airway colonization in COPD patients is an important factor in disease progression [62]. Several studies have found an association between airway bacterial load and markers of inflammation in COPD patients [63-65]. Whether this reflects a direct cause-effect relationship remains to be proven.

\section{Conclusion}

To our knowledge, this is the first case report on ET secondary to MRSA in an adult without signs of systemic infection. It is also the 3rd reported case of MRSA-related tracheitis in a non-ventilated adult and the 1st case of MRSA exudative tracheobronchitis associated with tracheobronchomalacia. Clinicians should be aware of the fact that tracheobronchomalacia can masquerade as asthma in adults and can predispose to the development of serious infections, including MRSA tracheobronchitis in non-ventilated adults. 


\section{References}

1 Metlay LA, Macpherson TA, Doshi N, Milley JR: Necrotizing tracheobronchitis in intubated newborns: a complication of assisted ventilation. Pediatr Pathol 1987;7:575-584.

$\checkmark 2$ Chechani V, Vasudevan VP, Kamholz SL: Necrotizing tracheobronchitis: complication of mechanical ventilation in an adult. South Med J 1991;84:271-273.

-3 Salamone FN, Bobbitt DB, Myer CM, Rutter MJ, Greinwald JH Jr: Bacterial tracheitis reexamined: is there a less severe manifestation? Otolaryngol Head Neck Surg 2004;131: 871-876.

4 Yamazaki Y, Hirai K, Honda T: Pseudomembranous tracheobronchitis caused by methicillin-resistant Staphylococcus aureus. Scand J Infect Dis 2002;34:211-213.

5 Namba Y, Mihara N, Tanaka M: Fulminant tracheobronchitis caused by methicillin-resistant Staphylococcus aureus (MRSA) (in Japnaese). Nihon Kyobu Shikkan Gakkai Zasshi 1997;35:969-973.

-6 Jones R, Santos JI, Overall JC Jr: Bacterial tracheitis. JAMA 1979;242:721-726.

7 Gallagher PG, Myer CM III: An approach to the diagnosis and treatment of membranous laryngotracheobronchitis in infants and children. Pediatr Emerg Care 1991;7:337342 .

8 Stroud RH, Friedman NR: An update on inflammatory disorders of the pediatric airway: epiglottitis, croup, and tracheitis. Am J Otolaryngol 2001;22:268-275.

-9 Nseir S, Favory R, Jozefowicz E, Decamps F, Dewavrin F, Brunin G, Di Pompeo C, Mathieu D, Durocher A, VAT Study Group: Antimicrobial treatment for ventilator-associated tracheobronchitis: a randomized, controlled, multicenter study. Crit Care 2008; 12:R62.

10 Palmer LB, Smaldone GC, Chen JJ, Baram D, Duan T, Monteforte M, Varela M, Tempone AK, O’Riordan T, Daroowalla F, Richman P: Aerosolized antibiotics and ventilator-associated tracheobronchitis in the intensive care unit. Crit Care Med 2008;36:2008-2013.

- 11 Nseir S, Di Pompeo C, Pronnier P, Beague S, Onimus T, Saulnier F, Grandbastien B, Mathieu D, Delvallez-Roussel M, Durocher A: Nosocomial tracheobronchitis in mechanically ventilated patients: incidence, aetiology and outcome. Eur Respir J 2002;20:14831489 .

-12 Martinez JA, Rodriguez E, Bastida T, Buges J, Torres M: Quantitative study of the bronchial bacterial flora in acute exacerbations of chronic bronchitis. Chest 1994;105:976.

13 Chastre J, Fagon JY: Ventilator-associated pneumonia. Am J Respir Crit Care Med 2002;165:867-903.

14 Craven DE: Preventing ventilator-associated pneumonia in adults: sowing seeds of change. Chest 2006;130:251-260.

-15 Foster TJ: The Staphylococcus aureus 'superbug'. J Clin Invest 2004;114:1693-1696.
6 Kampf G, Wischnewski N, Schulgen G, Schumacher M, Daschner F: Prevalence and risk factors for nosocomial lower respiratory tract infections in German hospitals. J Clin Epidemiol 1998;51:495-502.

17 Rello J, Ausina V, Castella J, Net A, Prats G: Nosocomial respiratory tract infections in multiple trauma patients. Influence of level of consciousness with implications for therapy. Chest 1992;102:525-529.

18 Nseir S, Di PC, Soubrier S, Lenci H, Delour P, Onimus T, Saulnier F, Mathieu D, Durocher A: Effect of ventilator-associated tracheobronchitis on outcome in patients without chronic respiratory failure: a case-control study. Crit Care 2005;9:238-245.

19 Palmer LB, Smaldone GC, Simon S, O'Riordan T, Morra L: Tracheal aspirates in long-term mechanically ventilated patients. A human model of gram-negative infection and airway inflammation. Chest 1995;108: 1326-1332.

20 Ahmed QA, Niederman MS: Respiratory infection in the chronically critically ill patient. Ventilator-associated pneumonia and tracheobronchitis. Clin Chest Med 2001;22: 71-85.

-21 Nseir S, Di Pompeo C, Soubrier S, Delour P, Onimus T, Saulnier F, Durocher A: Outcomes of ventilated COPD patients with nosocomial tracheobronchitis: a case-control study. Infection 2004;32:210-216.

22 Loosli CG: Influenza and the interaction of viruses and bacteria in respiratory infections. Medicine (Baltimore) 1973;52:369384.

23 Nelson WE: Bacterial croup: a historical perspective. J Pediatr 1984;105:52-55.

24 Craven DE, Kunches LM, Kilinsky V, Lichtenberg DA, Make BJ, McCabe WR: Risk factors for pneumonia and fatality in patients receiving continuous mechanical ventilation. Am Rev Respir Dis 1986;133:792-796.

- 25 Torres A, Aznar R, Gatell JM, Jimenez P, Gonzalez J, Ferrer A, Celis R, RodriguezRoisin R: Incidence, risk, and prognosis factors of nosocomial pneumonia in mechanically ventilated patients. Am Rev Respir Dis 1990;142:523-528.

26 Reynolds HY: Bacterial adherence to respiratory tract mucosa - a dynamic interaction leading to colonization. Semin Respir Infect 1987;2:8-19.

27 Patel IS, Seemungal TA, Wilks M, LloydOwen SJ, Donaldson GC, Wedzicha JA: Relationship between bacterial colonisation and the frequency, character, and severity of COPD exacerbations. Thorax 2002;57:759764.

28 Liston SL, Gehrz RC, Siegel LG, Tilelli J: Bacterial tracheitis. Am J Dis Child 1983;137: 764-767.

-29 Ernst TN, Philp M: Bacterial tracheitis caused by Branhamella catarrhalis. Pediatr Infect Dis J 1987;6:574.
30 Donnelly BW, McMillan JA, Weiner LB: Bacterial tracheitis: report of eight new cases and review. Rev Infect Dis 1990;12:729-735.

31 Garner JS, Jarvis WR, Emori TG, Horan TC, Hughes JM: CDC definitions for nosocomial infections, 1988. Am J Infect Control 1988; $16: 128-140$

32 Tsokos M, Zollner B, Feucht HH: Fatal influenza A infection with Staphylococcus aureus superinfection in a 49-year-old woman presenting as sudden death. Int J Legal Med 2005;119:40-43.

33 Stuchell B, Chinnis A, Davis S: Case report: bacterial tracheitis in an adult female. WV Med J 2003;99:154-155.

34 Comandini UV, Maggi P, Santopadre P, Monno R, Angarano G, Vullo V: Chlamydia pneumoniae respiratory infections among patients infected with the human immunodeficiency virus. Eur J Clin Microbiol Infect Dis 1997;16:720-726.

- 35 Dann EJ, Weinberger M, Gillis S, Parsonnet J, Shapiro M, Moses AE: Bacterial laryngotracheitis associated with toxic shock syndrome in an adult. Clin Infect Dis 1994;18: 437-439.

- 36 Luna CM, Legarreta G, Esteva H, Laffaire E, Jolly EC: Effect of tracheal dilatation and rupture on mechanical ventilation using a low-pressure cuff tube. Chest 1993;104:639640.

- 37 Valor RR, Polnitsky CA, Tanis DJ, Sherter CB: Bacterial tracheitis with upper airway obstruction in a patient with the acquired immunodeficiency syndrome. Am Rev Respir Dis 1992;146:1598-1599.

38 Craig TJ, Maguire FE, Wallace MR: Tracheobronchitis due to Corynebacterium pseudodiphtheriticum. South Med J 1991;84: 504-506.

39 Osakabe Y, Tazawa S, Kanesaka S, Narihara K, Takahashi Y: Four cases of airway infections caused by MRSA (methicillin-resistant Staphylococcus aureus) (in Japanese). Nihon Kyobu Shikkan Gakkai Zasshi 1990;28:368373.

40 Ruddy J: Bacterial tracheitis in a young adult. J Laryngol Otol 1988;102:656-657.

41 Campbell TP, Paris PM, Stewart RD: Tracheitis: the 'other' cause of upper airway obstruction. Ann Emerg Med 1988;17:66-68.

42 Johnson JT, Liston SL: Bacterial tracheitis in adults. Arch Otolaryngol Head Neck Surg 1987;113:204-205.

-43 Finegold SM, Johnson CC: Lower respiratory tract infection. Am J Med 1985;79:73-77.

44 Musher DM, Kubitschek KR, Crennan J, Baughn RE: Pneumonia and acute febrile tracheobronchitis due to haemophilus influenzae. Ann Intern Med 1983;99:444-450.

-45 Shamsuddin D, Tuazon CU: Clinical efficacy of cefoxitin in the treatment of head and neck infections. Arch Otolaryngol 1981;107:242244 
46 Bernstein T, Brilli R, Jacobs B: Is bacterial tracheitis changing? A 14-month experience in a pediatric intensive care unit. Clin Infect Dis 1998;27:458-462.

-47 Moreno F, Crisp C, Jorgensen JH, Patterson JE: Methicillin-resistant Staphylococcus aureus as a community organism. Clin Infect Dis 1995;21:1308-1312.

48 Sullivan J, Tobias JD: Preliminary experience with the use of oral linezolid in infants for the completion of antibiotic therapy in the outpatient setting after admission to the pediatric intensive care unit. Am J Ther 2006;13:473-477.

-49 Saralaya D, Peckham DG, Hulme B, Tobin CM, Denton M, Conway S, Etherington C: Serum and sputum concentrations following the oral administration of linezolid in adult patients with cystic fibrosis. J Antimicrob Chemother 2004;53:325-328.

50 Carden KA, Boiselle PM, Waltz DA, Ernst A: Tracheomalacia and tracheobronchomalacia in children and adults: an in-depth review. Chest 2005;127:984-1005.

-51 Filler RM, Messineo A, Vinograd I: Severe tracheomalacia associated with esophageal atresia: results of surgical treatment. J Pediatr Surg 1992;27:1136-1140.

52 Jokinen K, Palva T, Sutinen S, Nuutinen J: Acquired tracheobronchomalacia. Ann Clin Res 1977;9:52-57.
53 Gilkeson RC, Ciancibello LM, Hejal RB, Montenegro HD, Lange P: Tracheobronchomalacia: dynamic airway evaluation with multidetector CT. AJR Am J Roentgenol 2001;176:205-210.

54 Johnson TH, Mikita JJ, Wilson RJ, Feist JH Acquired tracheomalacia. Radiology 1973; 109:576-580.

55 Nagappan R, Parkin G, Wright CA, Walker CS, Vallance N, Buchanan D, Nazaretian S: Adult long-segment tracheal stenosis attributable to complete tracheal rings masquerading as asthma. Crit Care Med 2002;30: 238-240.

56 Heyer G, Saba S, Adamo R, Rush W, Soong G, Cheung A, Prince A: Staphylococcus aureus agr and sarA functions are required for invasive infection but not inflammatory responses in the lung. Infect Immun 2002;70: 127-133.

-57 Andrews MJ, Pearson FG: Incidence and pathogenesis of tracheal injury following cuffed tube tracheostomy with assisted ventilation: analysis of a two-year prospective study. Ann Surg 1971;173:249-263.

58 Phillips JR, Tripp TJ, Regelmann WE, Schlievert PM, Wangensteen OD: Staphylococcal alpha-toxin causes increased tracheal epithelial permeability. Pediatr Pulmonol 2006;41:1146-1152.

59 McHardy VU, Inglis JM, Calder MA, Crofton JW, Gregg I, Ryland DA, Taylor P, Chadwick M, Coombs D, Riddell RW: A study of infective and other factors in exacerbations of chronic bronchitis. Br J Dis Chest 1980;74: 228-238.
60 Gump DW, Phillips CA, Forsyth BR, McIntosh K, Lamborn KR, Stouch WH: Role of infection in chronic bronchitis. Am Rev Respir Dis 1976;113:465-474.

61 Sethi S, Evans N, Grant BJ, Murphy TF: New strains of bacteria and exacerbations of chronic obstructive pulmonary disease. $\mathrm{N}$ Engl J Med 2002;347:465-471.

62 Wilkinson TM, Patel IS, Wilks M, Donaldson GC, Wedzicha JA: Airway bacterial load and FEV1 decline in patients with chronic obstructive pulmonary disease. Am J Respir Crit Care Med 2003;167:1090-1095.

-63 Soler N, Ewig S, Torres A, Filella X, Gonzalez J, Zaubet A: Airway inflammation and bronchial microbial patterns in patients with stable chronic obstructive pulmonary disease. Eur Respir J 1999;14:1015-1022.

64 Hill AT, Campbell EJ, Hill SL, Bayley DL, Stockley RA: Association between airway bacterial load and markers of airway inflammation in patients with stable chronic bronchitis. Am J Med 2000;109:288-295.

65 Bresser P, Out TA, van Alphen L, Jansen HM, Lutter R: Airway inflammation in nonobstructive and obstructive chronic bronchitis with chronic haemophilus influenzae airway infection. Comparison with noninfected patients with chronic obstructive pulmonary disease. Am J Respir Crit Care Med 2000;162:947-952. 